\title{
Government-link Companies in the National Dual Training System Programme; an Analysis of Perception, Factors Constraints, and Resolution
}

\author{
Asnul Dahar Minghat \\ UTM Razak School of Engineering and Advanced \\ Technology, Universiti Teknologi Malaysia, \\ Kuala Lumpur, Malaysia \\ asnul@utm.my
}

\author{
Siti Salina Mustakim \\ Institute of Teacher Education \\ Ministry of Education \\ Cyberjaya, Malaysia \\ salina.mustakim@ipgm.edu.my
}

\begin{abstract}
The primary aim of the study is to evaluate the participation of Government-Linked Companies (GLCs) in the National Dual Training System (NDTS) Programme operated by the Department of Skills Development (DSD), Ministry of Human Resource. NDTS was launched in the year 2005 involving the participation of industries in GLCs. After 10 years of its implementation, it is essential to investigate the participation of industries in GLCs due to the present needs of preparing ' $k$ worker' via the provision of comprehensive training provided by the NDTS Programme. Data were collected quantitatively from 80 GLCs via a 5 Likert scale questionnaire. Overall findings indicated that; $30.8 \%$ of the respondents stated that GLC's perception towards NDTS programme is Average, 31\% Agree with the Factors Constraints on NDTS, and 37.5\% Agree with Resolution Factors associated with constraints participation between GLC and NDTS Programme. This study contributes to the network and collaboration between organizations and industries that could help to ensure graduates are able to face challenges globally.
\end{abstract}

Keywords: government-linked companies, national dual training system programme, skills development

\section{INTRODUCTION}

Vocational and technical training have become an important agenda in many countries around the world, especially secondary and tertiary education [1] According to Creswell [2], vocational and technical training are implemented in almost all African countries involved in formal learning. In Finland, vocational training is seen as key to the employee training process of the labour market, which involves a basic level of vocational training, retraining and advanced training to the employee [3]. In Germany, [4], and [5] claim that vocational dual system has been introduced with regards to training in vocational training institutions and training in the workplace. This system prepares graduates to gain experiences and vocational qualifications in two different situations, namely in institutions and in the workplace training. The similar system is used in Switzerland [6]. They refer the system as apprenticeship training in order to equip people with the skills of vocational and technical training institutes and industry.
The dual training system in Germany develops two-way features, which was implemented in the 20th century. The training of apprentice has begun since the 17 th century. The main goal of dual systems in Germany is a vast and universal education in vocational training, which provides all young people with certified qualifications. From the statistical point of law, it can be viewed as the provisions of law that established the Vocational Training Act of 1969 for training in the workplace and state Education Acts for training in schools. Dual systems in Germany take strong financial resources, where there is a cost sharing between the government and the industry. However, the industry accounted for a larger share of up to two-thirds of the total. The company itself monitors coordination and quality control. In fact, a company that is involved with a bunch of the dual programme carried out assessment and certification system. Curriculum and instructional design were only given a brief curriculum framework, a new concept in the field of learning, and only vary by company and vocational school.

Government-link Companies (GLC) is defined as companies with major commercial objectives and the Government has a controlling interest in the system. Control refers to the ability or the authority of the government of not just the percentage of ownership to appoint members of the Board of Directors, Senior Management, and making crucial decisions on GLC. It also relates to awarding contracts, strategies, restructuring and financing, acquisitions and divestments. Knowing the importance of GLC in the longterm prosperity of the nation, the Prime Minister has made a priority in the country. The transformation of GLC aims to create mending deep and lasting structure in the practice of the organization and the performance of GLCs, and in this case, the benefits are expected to obtain within the short-term, which the most of the long-term benefit is in next 5 to 10 years. GLC holds the role of the State in the form of successful development that is different from the conventional form of government agencies in a multilingual environment framework of roles and responsibilities.

GLC consists of companies controlled by the respective State Governments and agencies. Four GLC related sectors 
are (1) Economy, Land Transportation and Infrastructure, (2) Economy Sector, (3) Technology and Infrastructure Sector (Land Transportation), and (4) Social Sector. In between the private sector and the government, there are their own respective functions. The roles and responsibilities of each party are equally important. The private entity is to create economic development and wealth materials via marketing, while the government is responsible for the welfare of the community. Within the scope of the private entity, there is diversity in the form of business organization whether a sole proprietorship, partnership or incorporation. Moreover, in the context of the incorporation of the entity type, the shares in the company may be held entirely by the private sector or the government. Business entities equity held by the state is known as public companies or GLCs. Public enterprises are the entity that has long been accepted as one of the tools for governments of developing countries, including among western countries $[7,8,9,10]$. Public enterprises is a special organization that exists in most countries and called by various names such as 'parastatal', 'state-owned enterprise' and in Malaysia, public enterprises is also known by names such as 'government companies', 'off-budget agencies',' non-financial public enterprise' and 'statutory bodies'. Most countries build public enterprises companies that utilize a method of accelerating the economic development of the United Nations. In fact, in some countries, for example, Bangladesh, Bolivia, Mexico, India, Turkey, Chile and Ghana, public enterprises have become the dominant economic sector and affect the country's economy.

NDTS first enrollment began in 2005 with the recruitment of an apprentices group consisting of 29 people by Daimler Chrysler Malaysia and 14 by Naza Automotive Manufacturing Company to train them in the field of automotive mechatronics [11. It also involves a variety of accredited training centres of various ministries in countries such as the Industrial Training Institute (ITI), and the National Development Skills Institute (NDSI) [12]. The statistics of involvement of trainers accredited training centres and industrial companies continued to rise and acclaim from year to year during the implementation of NDTS. In December 2009 , there are about 22.000 workers who are undergoing or have completed a training program under the bilateral system which has involved about 1000 companies of different industries.

According to statistics released by the SEC itself, in December 2010 there were a total of 25.021 trainees who have completed a training program under the dual system, which involved about 1028 industrial and 119 accredited training centres [13]. According to statistics released, in the first phase of implementation NDTS carried out starting in 2005 until the year of 2010 did not succeed in fully achieving the target enrollment goal of producing a total of 31,500 skilled workers by 2010 as previously stated. In the early stages of its implementation in the year 2005, training institutions under the Ministry of Human Resources, the Ministry of Youth and Sports, Ministry of Higher Education were instructed to apply the system in skills and training programmes organized by
NDTS. The primary responsibilities to realize the effectiveness of this system are to (1) conduct training, (2) collaborate with companies that participate in this system and prepare and implement a training program, (3) provide training and other facilities needed, and (4) provide teachers with adequate levels of the instructors for about twenty trainees [14].

\section{RESEARCH METHOD}

This is a descriptive study to identify perceptions, factors constraints in GLCs' participation and determines solutions to the constraints to NDTS implementation. Descriptive studies can explain and describe a matter or situation at a time and help solve a problem through a "cause and effect" [15]. Research objectives of the study were (1) to determine GLCs' perception towards NDTS, (2) to determine GLCs' Factors Constraints on NDTS, and (3) to determine resolution factors associated with participation constraints between GLCs and NDTS. A descriptive study is suitable to be used in research that aims to explain events or circumstances taking place with the data in a certain time only and often using questionnaires [16].

The population of this study consisted of 115 GLCs from four sectors namely (1) Economy Sectors, (2) Infrastructure and Public Facilities, (3) Technology Sectors, and (4) Social Sectors. The four sectors were selected based on a simple random sampling of data collection technique in a quantitative method. Out of 115 GLCs involved, 13 GLCs were forbidden for data collection since they were selected for pilot study earlier. Thus, only 102 GLCs were identified for the population. 80 respondents answered the questionnaire. The instrument used in the study was a 5 Likert Scale Questionnaire, which consisted of structured writing arranged systematically according to a certain flow of thoughts.

\section{FINDINGS}

\section{A. Research Objective 1: To Determine GLC's Perception towards NDTS.}

In order to determine GLC's perception towards NDTS, Fig. 1 indicates that the Training Concept conducted by NDTS is scored as "Good" (47.5\%), which highlights 70 percent of hands-on-at-work and 30 percent of theoretical training in the training institutions. The Curriculum adopted by the National Occupational Core Curriculum (NOCC) developed in collaboration with industry is also presented as "Good" $(32.5 \%)$. Training Infrastructure used systematically and exposed to the latest technologies is also noted the perception of "Good" (37.5\%). The Technical Abilities of Apprentices in NDTS which meet the requirements of industries (48.8\%), Multi-Incentives of Apprentice involves in

NDTS (43.8\%), Multi-Incentives of Industries involves in NDTS (33.8\%), and the Image of Working in Industries $(36.2 \%)$ are all scored at the perception of Average. Only the GLC's perception towards NDTS pertaining to Social Abilities Apprentice is scored at the perception of satisfactorily (28.8\%). 


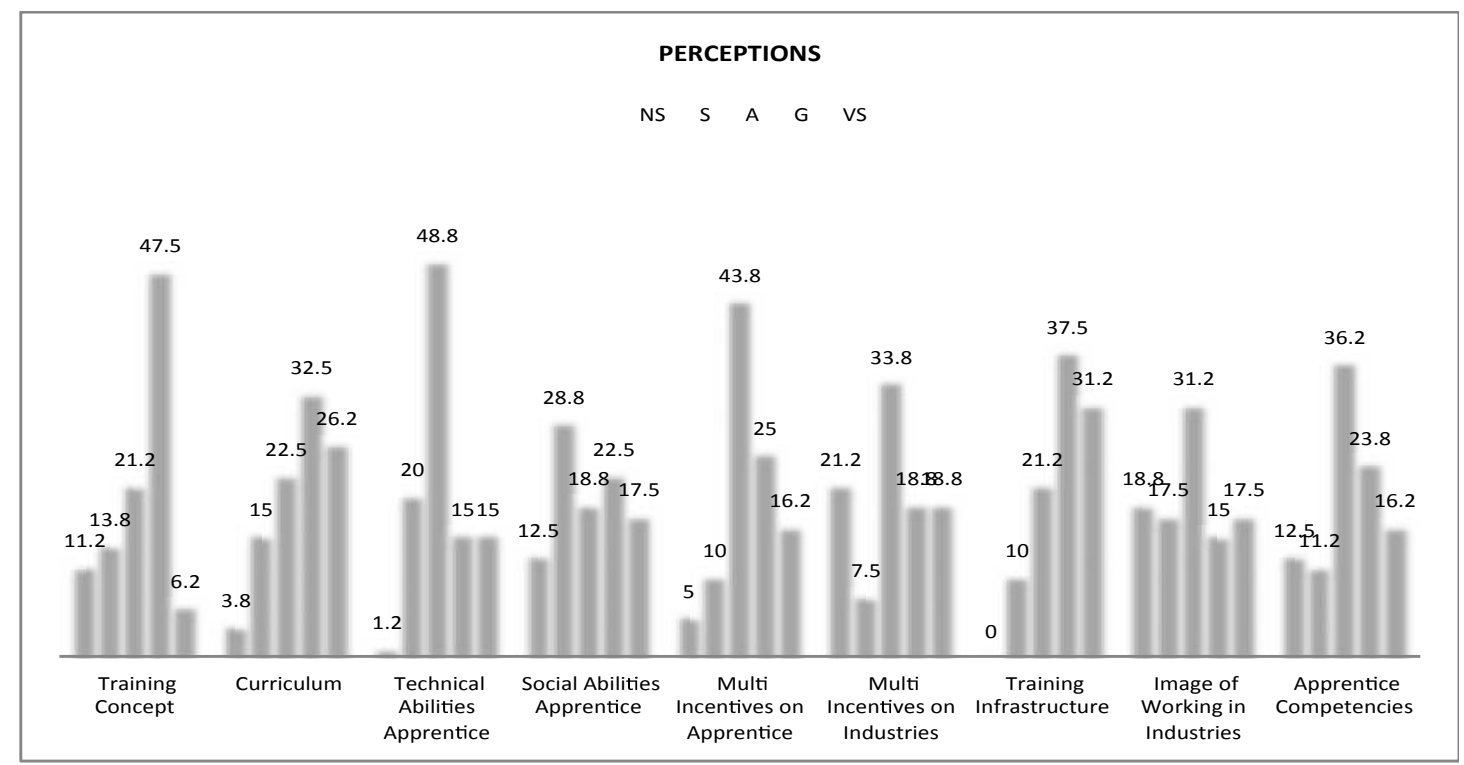

Fig. 1: GLCs Perception towards the NDTS Programme

\section{B. Research Objective 2: To determine GLC's Factors}

Constraints on NDTS

Fig. 2 indicates that only one score "Strongly Agree" is chosen by the GLC which refers to the attitude of the Company's Confidentiality's Attitude from being exposed outside with a score of $30 \%$. The GLC score "Agree" with some of the factors that lead to constraints on their participation in NDTS, and they claim that the certification by Department of Skills Development (DSD) is not widely recognized with a record of $35 \%$. The score of Agree to the Absence of Special Enforcement by the responsible bodies for duties of participation in industries, the promotion by DSD were limited about the existence of the NDTS, the Sufficient
Budget Allocation for the training burden in industries the Promotion of Advancement given to employees who enroll in NDTS, the Recruitment recently graduated from NDTS was a burden in industries due to a lot of extra training required in order to guide them to be more skillful are $32.5 \%, 32 / 5 \%$, $40 \%, 25 \%$, and $46.2 \%$ respectively. The duration of training is lengthy that creates boredom to the trainee which affects their work performance $(31.2 \%)$, the venue of training is too crowded which affect the quality of hands-on learning (35\%), less performance after the assessment (33.8\%), and an inappropriate NDTS Curriculum is disagreed by the respondents which providing the score of $32.5 \%$.

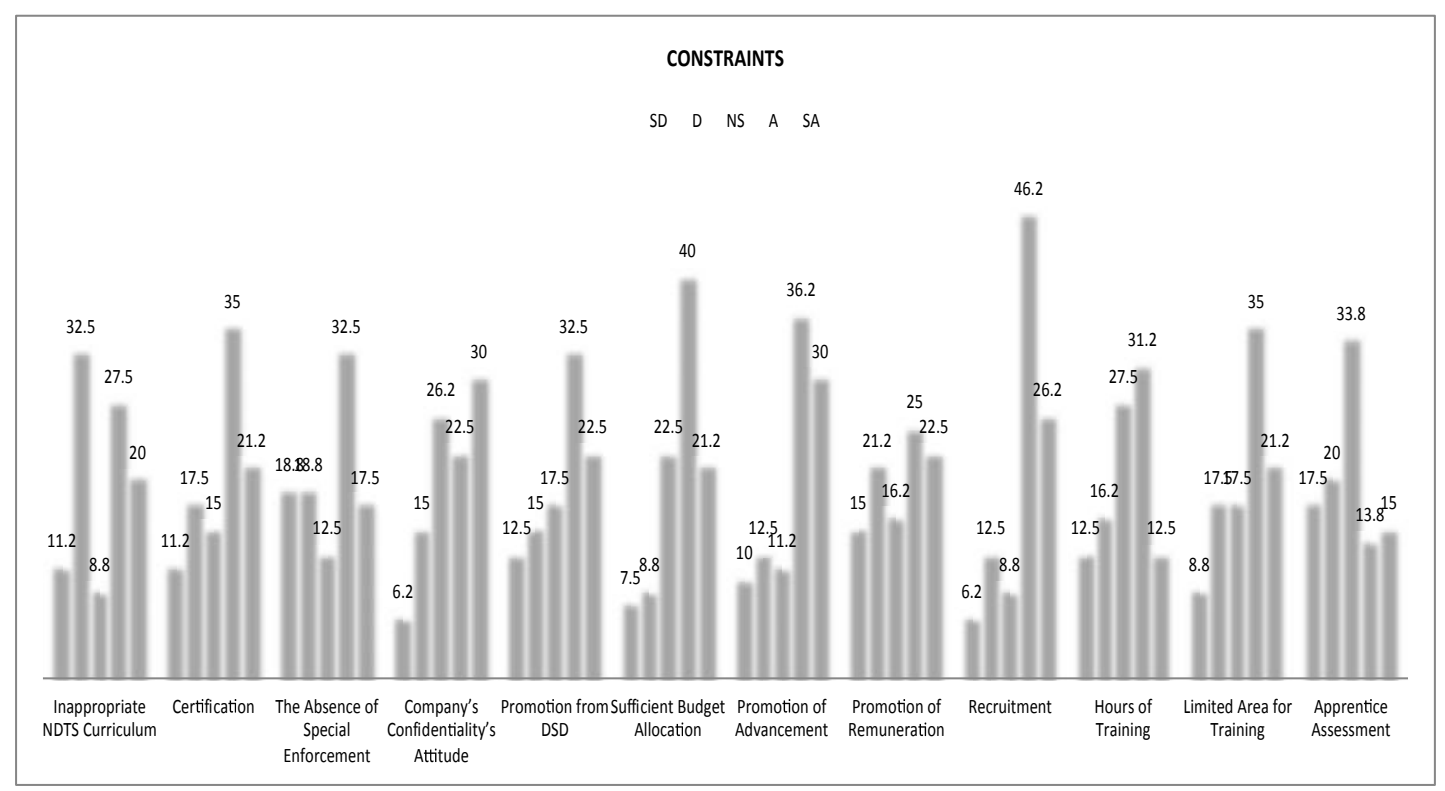

Fig. 2. GLCs Factors Constrains on NDTS Programme 


\section{Research Objective 3: To determine Resolution Factors} Associated with Constraints Participation between GLC and NDTS

Fig. 3. indicates resolution factors associated with the constraints of participation between GLC and NDTS highlights $41.2 \%$ pertaining to Incentive Promotion/Enhancement provided by NDTS, the ideas of developing NDTS programme scores $35 \%$ for experienced skilled worker, the utilization of flexible format in performing the task in industries scores at $40 \%$, methods of increasing the image of competent workers scores at $35 \%$, and suggestions of utilizing flexible mode of implementation scores at $38.8 \%$.
While respondents were Agree (40\%) to Certification of Other Programmes related to recognition of NDTS programme by others, increasing the image of Competent Worker scores at $35 \%$ by creating a category master craft men, Develop NDTS Training Programme $(45 \%)$ in order to reduce dependency on foreign workers, and Promotion and Exhibition highlights $37.5 \%$ that relate to providing platform of NDTS as a career path options. Out of those resolution factors feedback provided by respondents, only System Integration highlights Not Sure (30\%) about the resolution factors discussed between GLC and NDTS.

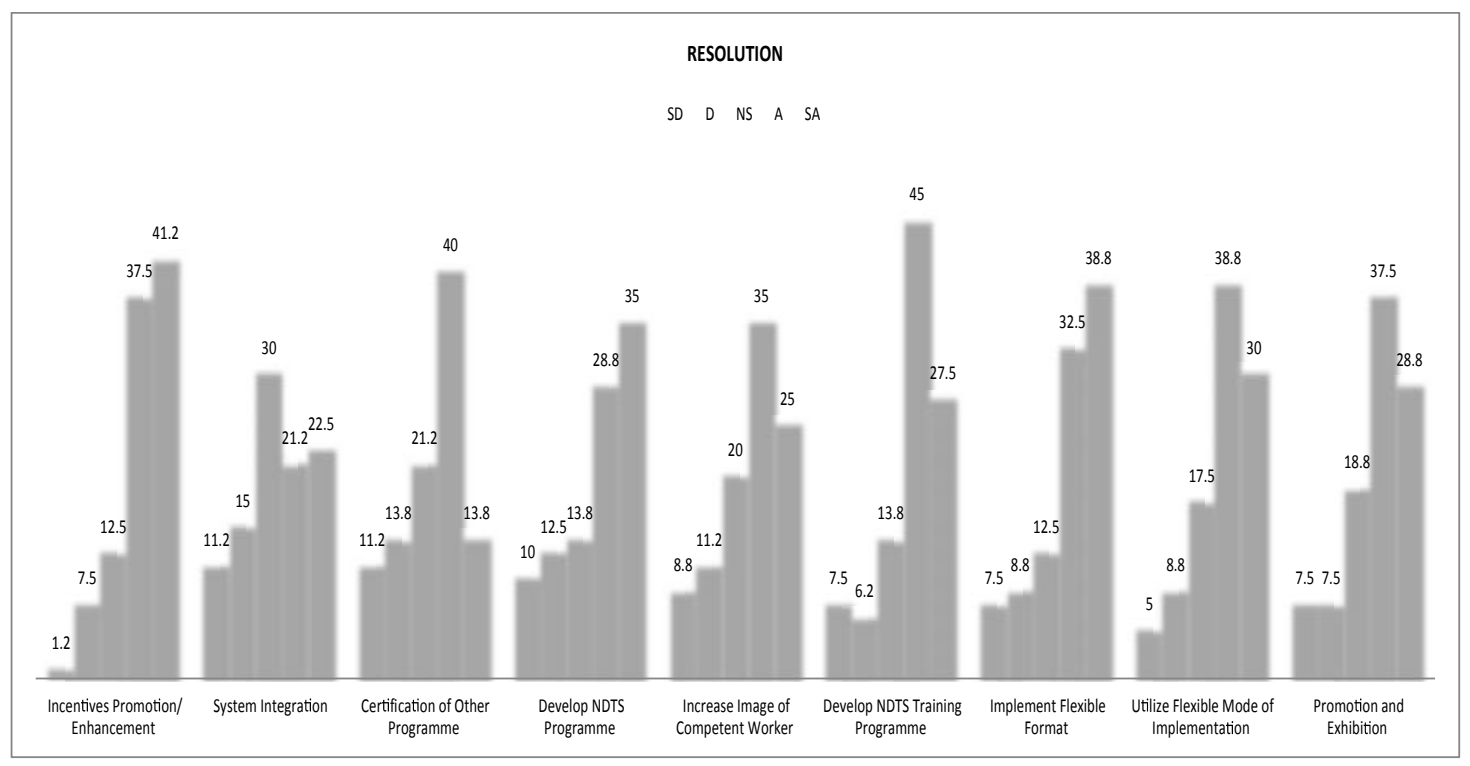

Fig. 3. Resolution Factors Associated with Constraints Participation between GLC and NDTS Programme

\section{DISCUSSION}

Average of the respondents feel a burden to a lot of additional training required during the NDTS programme which is in progress. Findings indicated respondents were uncertain about the constraints affecting the assessment of apprentice after their involvement in the industries. This was due to the misunderstanding of the person in charge to assess apprentices after the completion of their tasks. There were some industries that were less willing to cooperate with the NDTS programme. It was mentioned that the involvement of the curriculum in GLCs did not bring benefits to their industries. In other words, the curriculum provided by NDTS was less competent to their organization, causing the graduates who were not in-line with the needs of the employers. The mismatch curriculum by NOCC was not satisfying among the respondents. Majority of the respondents were not satisfied with the constraints in the participation of the programme on NDTS. This was due to maintaining the confidentiality of companies. In order to maintain the confidentiality among companies, it is much easier if NDTS have a network and collaboration with those organizations in GLCs.

Pertaining to the resolution factors associated with the participation of GLCs on NDTS, it was found that majority of
The respondents were very satisfied with the promotion of advancement/incentives to companies or industries that are associated with NDTS programme. The findings of the study showed the average of respondents strongly agreed with the solution to the constraints factors GLC participation in the program NDTS was to expand incentives to companies or industries that were working to bring the NDTS program. Financial incentives to industries are such as reducing the cost of hiring skilled workers in terms of training, evaluation, and selection of advertising. Eligible for tax deduction under the Income Tax Act 1967 or is entitled to payment of the exercise of the Human Resource Development Fund (HRDF) to companies or employers who qualify. If seen from the angle of perception that involves financial incentives, it is important for the organization because it gives motivation to them in the form of financial incentives which GLC grants, tax breaks and incentives for training. With this form of financial incentives, it can reduce the cost of hiring skilled workers from foreign countries. Findings are somewhat parallel to research conducted by [17] which states that the importance of incentive given to companies in the job training to improve the skills of workers proficient in the job. This helps companies to reduce the cost of hiring a professional in terms of financial 
factors. NDTS develops training programs to reduce dependency on foreign workers. This study was proven by [18] who found that students were more interested to venture into fashion designing business of working with companies as well as research and [19] stated that high-interest incomes encouraged students to undertake field of agriculture. This can reduce our dependence on foreign workers. In this context, students should be groomed into a well-balanced citizen of becoming a holistic society with professional skills' development. In order to fulfil this target, a comprehensive plan of the learning process which is defined as a change of attitude, improvement of knowledge and or skills as a result of a particular programme is required (20). It should be employed prior to the implementation of NDTS programme. The study by Reference [21] found that training programs could provide experiences related to culture and education that made a better learning and engaging and the students would also be provided with career significantly and more willing to work in the chosen career.

\section{CONCLUSION}

NDTS uses the concept of German dual system that is a comprehensive training system due to aspects of skills development, which emphasized the integration of knowledge, skills, values and language in the learning process [22]. Reference [23] in her study states that the latest technology is able to improve the quality of work since workers is trained in the industries based on the industrial needs. In order to increase productivity and relate it to NDTS to meet the job requirement, employers should supply relevant and sufficient skilled worker. The utilization of new technology is crucial for a skilled worker who is the basic platform, to be exposed to these new technologies in the initial stage. This worker later would be able to be competent in their job. The development of curriculum adopted by NOCC in collaboration with industries plays a great role in achieving competent skilled worker. The company and the training institutions cover theory and practical training in line with technology advances to produce a competent worker that should be carried out in the training. In relation to a satisfying perception on GLCs, the social skills apprentices in NDTS meet the industry needs. NDTS does not only help to improve the technical skills of apprentices with their collaboration among industries, but it improves social skills such as problem-solving, communication, and soft skills. This is consistent with a study conducted by [24] that all parties must jointly work together, to change the perception and stigma of the local community, in particular, to continue saying that vocational education is an alternative to those who have problems with socioeconomic status at the primary levels. There are various incentives for apprentices and industries involved in the NDTS programme. For instance, financial incentives to industries, such as reducing the cost of hiring skilled workers in terms of training, evaluation, and selection of advertising. In fact, the apprentices would get incentives in terms of monthly allowance with their recognized certification.

\section{REFERENCES}

[1] Asnul Dahar Minghat \& Siti Azizah. Factors Influencing Selection of Design and Tailoring Course in Muar. Universiti Teknology Malaysia. 2011.

[2] Creswell, J. educational research: planning, conducting, and evaluating. New Jersey : Pearson Education. 2013.

[3] Yahya Buntat \& Nor Mohd Zahari. Kesesuaian Kemahiran Asas Pertanian di Sekolah Menengah Teknik/Vokasional Pertanian ke Arah Persediaan Menceburi Bidang Usaha Tani.Fakulti Pendidikan Universiti Teknologi Malaysia. 2010.

[4] Abdul Aziz b.Ibrahim. Public Enterprises: The role, contribution and aspirations. Seminar of Future Public Enterprises. Gemaputra, Kuala Lumpur. 1990.

[5] Deissinger T. Germany's vocational train- ing act: Its function as an instrument of qual- ity control within a tradition-based vocational training system. Oxford Review of Education 22: 317-336. 1996

[6] Department of Skills Development Ministry of Human Resource, Malaysia. 2010

[7] Tilak, J., Vocational Education and Training In Asia. In: Keeves, P.J., Watanabe, R. (Eds.), The Handbook of Educational Research in the Asia Pacific Region. Kluwer Academic Publishers, Dordrecht. 2002.

[8] Agrawal, Meenu and Shobana Nelasco., Empowerment of Rural Women in India, New Delhi: Kanishka Publishers and distributors, 2009.

[9] Lundberg.C. Job Training in Japan: An Incentive to Increase Foreign Direct Investment. Prepared for the Japan Institute of Labour, Policy and Training (JILPT). Halaman 1-18. 2006.

[10] Pang Chau Leong, Rajamorganan Narunan \& Simon Sim. Background Paper For Malaysia: Skills Development In The Workplace In Malaysia. ILO/SKILLS-AP/Japan Regional Technical Workshop and Study Programme on Skills Training in The Workplace Overseas Vocational Training Association, Chiba, Japan. 2010.

[11] Pang, C.L. A Historical Account of Skills Training in Malaysia. In G. Loose, G.Spottl, \& Y. M. Sahir (eds). "Re-engineering dual training the Malaysian experience, 165-176. 2008.

[12] Gale, B. Politics and Public Enterprises in Malaysia. Kuala Lumpur: Eastern Universities Press. 1981.

[13] Sherwood, F.P. The Problem of the Public Enterprise.Dalam Frontiers of Development Administration, disunting oleh Rigss, F.W. 384-372. United States: Duke University Press. 1971.

[14] Shaharuddin Haji Haron. Challenges Facing Public Enterprise In The Year Ahead. Seminar Masa Depan Agensi Perusahaan Awam.Gemaputera, Kuala Lumpur 17-18 Mac:1-16. 1990.

[15] Bals, T.E. A lack of concentration. Pesticide Outlook. 242 - 245. 1999.

[16] Hanhart, Siegried and Sandra BossioCosts and Benefits of dual apprenticeship: Lessons from the Swiss System.International Labour Review. 137: 4: 483-500. 1998.

[17] Chen, H. T. Theory-driven evaluations. Newbury Park, CA: Sage. 1990.

[18] Vuori, J., \& Vesalainen, J. Labour market interventions as predictors of re-employment. 1999.

[19] Linn, P. L., Howard, A., \& Miller, E. The Handbook for Research in Cooperative Education and Internships. Mahwah, NJ: Lawrence Erlbaum Associates. 2004.

[20] Siti Marfu'ah, Istanto Wahyu Djatmiko \& Moh. Khairudin Learning Goals Achievement of a Teacher in Professional Development, Vol. 23, No. 3. Jurnal Pendidikan Teknologi dan Kejuruan. 2017.

[21] Department of Skills Development Ministry of Human Resource, Malaysia. 2005,

[22] Habsah Ismail \& Aminuddin Hassan. Holistic Education in Malaysia. European Journal of Social Sciences - Volume 9, Number 2. 2009.

[23] Department of Skills Development, Ministry of Human Resource, Malaysia. 2009

[24] Oketch, M.O. To Vocationalise or Not To Vocational? Perspectives on Current Trends and Issues in Technical and Vocational Education and Training (TVET) in Africa. International Journal of Educational Development, 27: 220-34. 2007. 